marked the rebirth of astronomy and the beginning of the Renaissance of science. The astrolabe is a circular star map that can be rotated so as to calculate the positions of the Sun and the stars at any time of any day of the year; it could also be used for simple observations. The style of the instrument and its special arrangement of star pointers were copied by later workers, and the exquisite craftsmanship pointed clearly the way of later precision instruments. The instrument was presented to Dr. William Somerville (husband of Mary Somerville, after whom Somerville Hall, Oxford, was named) in Rome; he gave it to his friend, Sir John Herschel. It has remained in the Herschel family ever since and has now been lent to the Museum by Commander M. $H$. Hardcastle, R.N.

\section{Council of Europe Competition in Advanced European Research}

A PRIZE of one million French francs is to be awarded every two years by the Secretariat-General of the Council of Europe for an original thesis of high academic standard on a given subject of European importance. It must not have been previously published, and must represent an original contribution on the subject set. The subject chosen for the first competition is "Consequences of the Use of Nuclear Energy for the European Mode of Life". Theses may be written in English, Dutch, French, German, Italian or Spanish, and entries must be submitted before the end of 1960. A jury, chosen by the Secretariat-General on the advice of the Committee of Cultural Experts of the Council of Europe, will award the prize. Further information can be obtained from the Secretariat-General, Council of Europe, Strasbourg, France.

\section{Support for Institutes for Advanced Study in Science}

THE North Atlantic Treaty Organization has established a fund to provide financial assistance to institutes and summer schools for advanced scientific study in those cases where a large degree of international participation is anticipated among both the faculty and the students. No precise pattern has been defined for eligible institutes, but it is expected that the programmes will normally last between two weeks and two months, will be at a postgraduate or higher level, and will provide for concentrated study of a restricted scientific field. It is hoped that this fund will encourage the establishment of institutes for advanced study similar to the highly successful summer schools of theoretical physics at Les Houches and Varenna, but in other scientifie fields. Institutes and summer schools for advanced study in any of the natural sciences or technology may appropriately apply for grants. Although the eligible institutes must be situated in one of the fifteen member nations of the North Atlantic Treaty Organization, no nationality or other restrictions for either the staff or the students are in any way implied. Further information on the programme can be obtained from the Science Adviser, NATO Headquarters, Palais de Chaillot, Paris XVI, to whom applications for grants should be made.

\section{Reform of the Calendar}

A BRIEF review of the history of the calendar by Y. G. Perel (Priroda, 7, 47; 1958) suggests the urgent desirability of establishing a world calendar, such as was proposed by India in 1953 before the
United Nations. According to this proposal, the year will be divided into four quarters of thirteen weeks each, with the first month of thirty-one days and the following two of thirty days each. An additional day (the day of peace and friendship) is added after December 30, and on leap years an additional day after June 30.

\section{The Rockefeller Institute Press}

THE Rockefeller Institute Press has been established to publish books on science and related subjects in association with the Oxford University Press, New York. Editorial responsibility for the books will rest primarily with the Institute, while Oxford will be chiefly responsible for design, printing and distribution. It is expected that the first books will be issued in the autumn of 1959. While many of the books and monographs will be the work of Institute faculty members, works by others will also be published. The Rockefeller Institute Press will be under the direction of Charles I. Campbell, administrative associate for information services at the Institute.

\section{Lapis}

Lapis, a monthly journal of industrial opportunities, the first number of which appeared in October 1958 (pp. 28. Subscriptian rates, including postage for one year : inland, $£ 1010 s$. $0 d$.; abroad, U.S.A. and Canada, 30 dollars; France, 15,000 francs ; Italy, 19,000 lire. London: Kenneth Mason, 1 Old Burlington Street, W.1), lists patents available for disposal by licence or sale. These are classified in two parts : general, mechanical and electrical ; and chemistry and chemical engineering. There is also a list of agents and agencies wanted. Details of patents for disposal and partnerships for development are sought from all over the world.

\section{National Museum of Wales}

THE annual report of the National Museum of Wales for 1957-58, after giving details of the personnel of Court, Council and staff, records that the third application to the Treasury for permission to establish a Department of Industry was granted. A sum of $£ 2,000$ was provided for this purpose. To supplement this an appeal for $£ 5,000$ has been addressed to local industrialists. The keeper of geology, Dr. F. J. North, acted as keeper of the new Department, and in addition to arranging a typical exhibit illustrating the development of the miners' safety lamp, was able to establish some useful contacts for the future. An impressive series of seventeen temporary exhibitions was arranged during the year. In the Department of Geology the emphasis has been on the reserve and study collections, while the chief task of the Department of Botany was to organize an exhibition illustrating paper and its uses. In the Glanely Gallery three cases, "Animals without. Backbones", "Butterflies and Moths" and "The Main Group of Insects", were entirely re-arranged, while in the Department of Archæology reorganiza. tion has continued. In the Department of Art displays of Sheffield plate, the regalia of the Gorsedd of Wales have been added and other exhibits enlarged. The Welsh Folk Museum was chiefly concerned during the year with the re-erection of three houses from Cilewent, Radnorshire; Hendre'r-Wydd, Denbighshire; and Llandfadyn, Caernarvonshire. Such a record of progress in all Departments is a measure of the devotion of the staff of this Museum to the interests of the community. 